\title{
Corporate Governance and Profitability of Nigerian Banks
}

\author{
AKINYOMI Oladele John (Corresponding Author) \\ Department of Accounting and Finance, \\ McPherson University, Ogun State, Nigeria \\ E-mail: delejohn21@yahoo.com, akinyomio@gmail.com \\ OLUTOYE Ebenezer Adedayo \\ Banking and Finance Department, \\ Afe Babalola University, Ado Ekiti, Ekiti State, Nigeria \\ E-mail: olutoyedayo@yahoo.com
}

Received: Nov. 3, 2014 Accepted: May 22, $2015 \quad$ Published: June 10, 2015

doi:10.5296/ajfa.v7i1.6543 URL: http://dx.doi.org/10.5296/ajfa.v7i1.6543

\begin{abstract}
The Nigerian banking environment is a vibrant and challenging financial environment and is endemic with systemic governance problems, capacity constraints and defaulting in compliance and implementation of laws which has inhibited economic growth. Therefore the current investigation focuses on association between organizational governance and profitability of deposits money banks in Nigeria. Three indicators of corporate governance mechanism (board composition, board size and directors' interests) were incorporated in the study. Relevant information was extracted from audited financial statements of the selected banks. The results of the regression analysis revealed the existence of positive but non-statistically significant association between board composition and profitability on one hand; and board size and profitability on the other hand. However, a non beneficial and non-significant association exists between directors' interests and profitability in the Nigerian banks. Based on the findings of the study, the study recommends that in order to prevent distress in the banking sector, there should be a regular review of the corporate governance codes so as to reflect current social, environmental, technological and economic situations.
\end{abstract}

Keywords: Board Composition, Board Size, Directors' Interests, Profitability 


\section{Background}

The Nigerian banking environment is a vibrant and challenging financial environment and is endemic with systemic governance problems, capacity constraints and defaulting in compliance and implementation of laws which has inhibited economic growth (Suberu \& Aremu, 2010). This requires enhanced investigations, and more detailed reporting of activities. The penalties of organizational collapse are very expensive for an emerging economy such as Nigeria (Mohammed, 2012). Mmadu (2013) reported that the global economic crisis and the decline in the value of investment collections of deposit money banks particularly in Nigeria are due to distorted credit management and this problem can be traced to poor corporate governance. Schjoedt (2000) (as cited in Mmadu, 2013) also observed that this was as a result of the association amongst the financial institutions, politicians and large-size enterprises. Prior to the introduction of new prudential guidelines in Nigeria, which culminated in the consolidation of the banking industry; there were about 89 active players with dull performance, cases of negligent and reckless managers and directors and the reign of ethical abuses (Mmadu, 2013). Bad business governance remains one of the most important causes in almost all reported cases of bank failure in Nigeria.

The pre-consolidation era was characterized by poor organizational governance which manifests in form of inadequate internal control mechanisms, fraudulent practices, non-compliance to limits of authority, failure in paying attention to principles of discreet lending, nonexistence of risk management procedures, and override of internal control measures (Mmadu, 2013). Thus, the current investigation focuses on the relevance of organizational governance on earnings in the context of the Nigerian banking sector. The following hypotheses were formulated in order to achieve the set objective:

$\mathrm{Ho}_{\mathrm{i}}$ : There is no significant relationship between board size and bank's financial performance.

$\mathrm{Ho}_{i i}$ : There is no significant relationship between board composition and bank's financial performance.

$\mathrm{Ho}_{\text {iii }}$ : There is no significant relationship between director's interest and corporate financial performance.

\section{Extant Literature}

Wessels and Wansbeek (2014) relate governance to the exercise of authority, direction and control. It is a concept that has a history that could be traced to Chaucer, which carries with it the implication of prudence (Uwuigbe, 2011). Organizational governance represents a number of procedures, habits, pattern of operations, and rules that influence the manner an organization is governed (Dar, Naseem, Rehman, \& Niazi, 2011).

Corporate governance represent methods through which organizations are being administered, a structure through which the welfare of different parties with vested interests are harmonized, showing group of interaction between a company's administration, its board, its shareholders and other interested parties (Cheema \& Din, 2013). It involves the interaction among the 
many interested parties concerned and the reasons while the corporation is being managed (Dar, Naseem, Rehman, \& Niazi, 2011). Organizational governance represents a noteworthy variable which establish the strength of the organization and the company's capability to live through financial shake-ups (Uwuigbe, 2011). The overall focus of organizational governance has to do with developing reliability, guaranteeing openness and responsibility (Uwuigbe \& Fakile, 2012).

The merits of good corporate governance are evidenced in its role towards financial firmness through corporate profitability improvement and boosting organizational opportunities to obtain outside funds, serving government policy goal, lowering vulnerability of the economic disaster, and reducing expenditure incurred in obtaining funds (Latif, Shahid, Haq, Waqas, \& Aeshad, 2013). Good governance also encourages support and assurance in the banking system (Mohammed, 2012).

\subsection{The Board of Directors and its Size}

It is the responsibility of the board of directors to guarantee that the business is enjoying maximum benefits of prevailing occasions and ensuring that the economic worth of the organization is enhanced, being successful when its ability to make choices and affect the administrators is incredibly strong (Uwuigbe \& Fakile, 2012).

The board should check the behaviours of managers for owners' welfare, decide on crucial issues, hire set of administrative officers and oversee that organizations adhere to the rule while taking responsibility for managing and supervising (Akinyomi, 2013). The Board of Directors uses its powers and responsibilities within the structure of legislation, main contract, regulations and policies, and represents the company in line with the authority given to it at the general meeting of shareholders (Dogan \& Yildiz, 2013). The economic worth of an organization would further be enhanced as the board carries out its functions which include supervision of the operations of administrative officers and choosing the employees of an enterprise, appointing and monitoring the activities of an autonomous auditor to boost the worth of the company (Uwuigbe, 2011).

When the number of board membership goes up, there would be possibility for divergent opinions which could result in more confusion among board membership (Dar, Naseem, Rehman \& Niazi, 2011; Adegbemi, Donald \& Ismail, 2012). Previous studies on this concept observed that organizations select size of board to create equilibrium between the requirements for timely advice and the financial implications of maintaining large board membership (Akinyomi, 2013). The board of Directors performs its duties in the form that it would ensure and provide a long term and stable earnings to the company shareholders while aiming at the maximization of market facilities by the companies (Dogan \& Yildiz, 2013). The board includes internal and external directors (Akinyomi, 2013); whose role includes chief executive officers' and organizational administrators' regulation in order to boost the economic worth of the company (Uwuigbe, 2011).

\subsection{Firm Performance}

Profitability is one of the major reasons for the existence of business enterprises (Akinyomi 
\& Olagunju, 2013), and business enterprises continue their operation by making profits (Ayse, 2013). Organizational performance has to do with the approach and method by which things of economic value existing in a corporation are prudently utilized for the achievement of the general business goal of a particular enterprise (Latif, Shahid, Haq, Waqas \& Aeshad, 2013; Akinyomi, 2014). Banks are business enterprises and as such their aim is to make profits just like any other profit making organizations. In this regard, the profitability which is an indicator of economic result of any organization indicates the success of its management, which also makes it one of the most important indicators for the investors (Ayse, 2013).

The current study anchors on some theoretical foundations, particularly the stakeholder and agency theories. These were selected because of their relevance to the composition of the hierarchy of corporation and the functions of the directors, with respect to reporting to the shareholders

\subsection{Stakeholder Theory}

According to Akinsulire (2011), there are diverse sets of individuals with vested interests in any organization. These include the ordinary and preference shareholders, providers of funds, workforce, those who supply materials used by the organization, consumers and general public. Every member of these sets of individuals have to be rewarded a smallest amount as the removal of their involvement could result in the shutting down of the business (Akinyomi, Enahoro \& Olutoye, 2013). Since institutions do not exist to serve their own purposes alone (Agle, Donaldon, Freeman, Jensen, Mitchell, Wood, 2007), the company's continuous existence depends on meeting together its financial and non-financial goals by satisfying the different demands of the organization's diverse interested parties (Pirsch, Gupter \& Grau, 2007). Stakeholder theory could be expressed in two main enquiries (Freeman,1994). These two main enquiries include inquiry on the objective of the organization and also what is the responsibility of management to the stakeholders.

\subsection{Agency Theory}

There has been a focus on the agency theory with emphasis on the principal-agent problem (Sami, Wang \& Zhou, 2009); the theory which has its foundation in economic theory has become dominant in the corporate governance literature (Uwuigbe, 2011). The theory asserts that most of the time, the objectives of the organizational administrator do conflict with those of the real owners of the business. This means that business owners have to connect their economic rewards with salaries and other remuneration of the organization's administrators. The moment it becomes difficult to predict the way business administrators would behave, and then their remuneration becomes a governance issue geared towards motivating them to carry out their duties in the best interest of the owners (Vo \& Phan, 2013). The theory agrees with the designation and absorption of leadership of members of the board and the utilization of encouraging remuneration packages, while the board monitors the managers by means of periodic reporting, evaluation and the adoption of laid down guidelines (Uwuigbe, 2011).

In spite of the fact that some studies on agency theory recommends that appropriate governance may possibly minimize agency expenses and boost the earnings of business 
owners, some results of other investigations suggest otherwise. One likely explanation to this divergence of results may be the utilization of different indicators of organization governance (Sami, Wang \& Zhou, 2009). In organizations, owners-managers conflict happens in situation where the interest of managers contradicts that of the owners (Sami, Wang, \& Zhou, 2009). The theory presents a structure to provide explanation on the ways to ensure efficiency in supervision and motivation system in situations of partial and imperfect knowledge (Sami, Wang, \& Zhou, 2009).

\subsection{Empirical Review}

There are several studies conducted in the past which focused on organizational governance (Wessels \& Wansbeek, 2014). Therefore, this review is eclectic in that it considers the investigation of corporate governance and corporate performance from several countries: Denmark, China, Bangladeshi, Pakistan, Sri Lanka and of course, the United States.

Bennedsen, Kongsted and Nielsen (2007) used data comprised of the entire public companies in Denmark during the period ended 1999. Chief executive officer's family characteristics were the major approach in determining the influence of size of board membership on organizational profitability. They used six thousand eight hundred and fifty companies, extracting data on chief executive officer's family features. They re-examined the existence of any association between size of board membership and organizational profitability. The report of the ordinary least square analysis showed the presence of a high favourable association between board size and family size. It further indicated that such an association was facilitated in companies where the chief executive officer's family members were board members.

Bhagat and Bolton (2009) related corporate governnace to performance in the light of the Sarbanes-Oxley Act. They separated the companies on the basis of time-frame of prior to year 2002, and the second group beginning from year 2002 upwards. This was done to reveal how the different regulations could have affected the companies' profitability within the time periods. Relevant information was extracted from Risk-Metrics Directors and Governance databases. Put together, it was reported that there was variation in the association between board independence and companies' profitability in the pre- and post- 2002 era. The study documented a negative association between board independence and profitability in the pre 2002 era. Meanwhile in the post 2002 era, they found a positive association between board independence and operating performance.

In China, Sami, Wang and Zhou (2009) made their study stand out by using a compound indicators of organizational governance in investigating the effect of organizational governance on firm profitability and appraisal in China. With a theoretical foundation in the agency theory, return on assets, return on equity and Tobin's Q were used as the dependent variables in their model. The outcome of the investigation supported the hypothesis that concentration of shareholders and board independence has favourable effects on organizational profitability and appraisal. 
Kutubi (2011) gave a closer look at the board, with emphasis on its size and the independence of its directors. The study investigated the association between bank board size, independent directors and profitability of Bangladeshi commercial bank after the prudential regulation issued in the country; using a sample of selected banks for the period 2005-2009. Bank performance was measured with ROA and ROE, alongside the Tobin's Q. Understanding the behaviour of directors on the performance of the banking firm was the justifiable reason for the use of the effect of size, leverage and performance of loan as control variable. The outcome of the analysis indicated a statistically significant positive association between Bangladeshi banks' board size and their profitability in terms of Tobin's Q, but no significant relation in terms of ROE and ROA.

A study was conducted in Pakistan on the association between organizational governance system and organizational performance indicators for a period between year 2004 and 2010 (Dar, Naseem, Rehman \& Niazi, 2011). The study highlighted some failures in Pakistan which were caused by lack of corporate governance. The regression analysis showed that profit margin is positively correlated with the firm's board size. The study reported that larger board size enhances profitability of the organizations.

In Sri Lanka, Danoshana and Ravivathani (2013) carried out an investigation on the association between organizational governance and profitability. Data for the study were subjected to regression analysis; and the result revealed that organizational governance mechanisms of board size, how often they meet and the size of audit team have considerable effect on organizational profitability. While board size and size of audit team are favourably associated with organizational profitability; how often they meet has a negative relationship with firm performance.

Another investigation on organizational governance was carried out in Pakistan with specific data drawn from the cement industry. The investigation considered the association between organizational governance and companies' profitability (Cheema \& Din, 2013). Panel data covering 15 organizations operating between 2007 and 2011 in the cement sector in Pakistan was used. Relevant information was extracted from financial statements of the selected companies. The results showed that board size has no considerable association with profitability; meanwhile chief executive officers' duality has effect of organizational profitability.

Wessels and Wansbeek (2014) focused their discussion paper on the existence of noteworthy association between organizational governance arrangements and its profitability. Data were obtained from business organizations in the United States of America in order to evaluate the existence of association between governance and corporate earnings. The findings of their investigation indicated the existence of noteworthy association between governance and corporate earnings. The interpretation given to the result was that it provided support that organizations decide to put into operation efficient organizational governance mechanisms considering the prevailing occasions. On the other hand, when the effect of the investment opportunity set was not accounted for, they could calculate the unconditional correlation between governance and performance. 


\section{$\Lambda$ Macrothink}

The study of Uwuigbe (2011) set out to examine the correlations of relationships between financial performance of banks and each of the following: board size, existence of foreign directors, ratio of non executive directors, directors' equity interest, and organizational governance disclosure, The investigation further inquire whether there was considerable distinction between the earnings of strong banks and those of weak commercial institutions. For ascertaining the degree of organizational governance disclosure in the banks, the investigation employed content analysis in obtaining relevant information from the financial statements of the financial institutions, while the panel data methodology was used. The regression analysis revealed the existence of noteworthy but unfavourable association between board size and profitability. The regression result for outside directors showed unfavourable association with profitability. The regression result for directors' equity holding showed positive relationship with performance. For government disclosures, the finding showed favourable and considerable association with performance.

\section{Material and Methods}

This study employed correlational research design. Four banks were randomly selected from the existing twenty-two banks in Nigeria as at the end of year 2013. The study was based on information obtained from annual reports of selected commercial institutions in Nigeria for the period 2008-2012. The analysis was carried out using regression model. The model for the study is as follows: $Y=\beta_{0}+\beta_{1} X_{1}+\beta_{2} X_{2}+\beta_{3} X_{3}+\mu$

Where, Y= Dependent variable (Bank's profitability)

$\beta_{0}=$ Intercept coefficient

$\beta_{1}=$ Standardized regression coefficient for each of the independent variables.

$\mathrm{X}_{1}=$ Board size

$\mathrm{X}_{2}=$ Board composition

$\mathrm{X}_{3}=$ Directors' interest

$\mu=$ Stochastic variable.

\section{Results and Discussion}

The data analysis result is presented in table 1 below; this was immediately followed by the interpretation and discussion of the findings.

Table 1. Regression Result with ROE as Dependent Variable

\begin{tabular}{|l|l|l|l|l|}
\hline Variable & Coefficient & Std. Error & T-Statistics & Probability \\
\hline Board Composition & 0.016 & 0.021 & 0.754 & 0.461 \\
\hline Board Size & 0.123 & 0.131 & 0.933 & 0.363 \\
\hline Directors' Interests & -0.634 & 0.653 & -0.971 & 0.344 \\
\hline
\end{tabular}

Source: Researcher's Computation (2014) 
The result revealed the existence of a positive relationship between board composition and profitability. However, the probability of $t$ test of profitability is not statistically significant at $5 \%$ with $p$ value of 0.461 which is greater than critical value of 0.05 for board composition; while the coefficient value on ROE is 0.016 . This connotes that there is no statistically significant relationship between board composition and profitability in the Nigerian banks. Return on equity will be increase by $2 \%$ if board composition changes by one. This means change in board composition will not result in high financial performance.

Similarly, the result revealed the existence of a positive relationship between board size and profitability. This means that the larger the board size, the more effective the board becomes in monitoring banks' managers. However, the probability of t test of profitability is not statistically significant at $5 \%$ with $p$ value of 0.363 which is greater than critical value of 0.05 for board size; while the coefficient value on ROE is 0.123 . This connotes that there is no statistically significant relationship between board size and profitability in the Nigerian banks. Return on equity will be increase by $12 \%$ when board size increases by one person. This means increase in board size will not result in high financial performance.

However, the result revealed the existence of a negative relationship between directors' interest and profitability. Nevertheless, the probability of $t$ test of profitability is not statistically significant at $5 \%$ with $p$ value of 0.344 which is greater than critical value of 0.05 for directors' interests; while the coefficient value on ROE is 0.634 . This connotes that there is no statistically significant relationship between directors' interests and profitability in the Nigerian banks. Return on equity will be reduced by $63 \%$ when directors' interests increase by one unit. This means increase in directors' interests will not result in high financial performance.

\section{Conclusion and Recommendations}

The current investigation focuses on the effect of organizational governance on the profitability of commercial banks in Nigeria. Three indicators of corporate governance mechanism (board composition, board size and directors' interests) were incorporated in the study. Data were obtained from audited annual reports of the selected banks. The results of the literature review and data analysis revealed the existence of a positive but non-significant relationship between board composition and profitability on one hand; and between board size and profitability on the other hand. However, a negative but non-significant relationship exists between directors' interests and profitability in the Nigerian banks. Based on the findings of the current study, the following recommendation has been put forward. In order to prevent distress in the banking sector, there should be a regular review of the corporate governance codes so as to reflect current social, environmental, technological and economic situations.

\section{Acknowledgement}

The authors acknowledge and appreciate the efforts of Mr Sanusi Adebisi who served as a Research Assistant in the course of conducting this study. 


\section{References}

Adegbemi, B. O., Donald, I. O., \& Ismail, O. F. (2012). Corporate governance and bank performance: A pooled study of selected banks in Nigeria. European Scientific Journal, 8(28), 155-164. Available at: www.eujournal.org/index.php/esj/article/view/644

Agle, B., Donaldson, T., Freeman, E., Jensen, M., Mitchell, R., \& Wood, D. (2007). Dialogue: Toward superior stakeholder theory. London: Cambridge University Press

Akinsulire, O. (2011). Financial management (7th ed.). Lagos: El-Toda Ventures Ltd.

Akinyomi, O. J. (2013). Impact of board structure on corporate financial performance. International Journal of Research in Commerce, IT and Management, 3(6), 135-139. Available at: www.ijrcm.org.in/it/index.php?type=Archives\&year=2013

Akinyomi, O. J. (2014). Relationship between dividend payout and financial performance of manufacturing firms in Nigeria. Journal of Emerging Issues in Accounting and Finance, 1(1), 6-17. Available at: www.susmijournal.org/

Akinyomi, O. J., Enahoro J. A., \& Olutoye, A. E. (2013). Corporate social responsibility and financial performance: Evidence from Nigerian manufacturing sector. Asian Journal of Management Research, 4(1), 153-162. . Available at: www.ipublishing.co.in/EIJMRS4014p

Akinyomi, O. J., \& Olagunju, A. (2013). Effect of firm size on profitability: Evidence from Nigerian manufacturing sector. Prime Journals of Business Administration and Management, 3(9), 1171-1175. Available at: www.primejournal.org/BAM/abstracts/2013/sep/Akinyomi\%20and\%20Olagunju.html

Ayse, A. Y. (2013). Profitability of banking system: Evidence from emerging markets. WEI International Academic Conference Proceedings (pp. 105-111). Antlaya, Turkey

Bennedsen, M., Kongsted, H. C., \& Nielsen, K. M. (2007). The causal effect of board size in the performance of small and medium-sized firms. Journal of Banking \& Finance, 32, 1098-1109.

Bhagat, S., \& Bolton, B. (2009). Corporate governance and firm performance: Recent evidence. Journal of Corporate Finance, 14(3), 257-273

Cheema, K. U., \& Din, M. S. (2013). Impact of corporate governance on performance of firms: A case study of cement industry in Pakistan. Journal of Business and Management Sciences, 1(4), 44-46.

Danoshana, S., \& Ravivathani, T. (2013). The impact of the corporate governance on firm performance: A study on financial institutions in Sri Lanka. Merit Research Journal ofAccounting, Auditing, Economics and Finance, 1(6), 118-121.

Dar, L. A., Naseem, M. A., Rehman, R. U., \& Niazi, G. S. (2011). Corporate governance and firm performance: A case study of Pakistan oil and gas companies listed in Karachi Stock Exchange. Global journal of management and business research, 11(8), 1-9. 
Dogan, M., \& Yildiz, F. (2013). The impact of the board of directors' size on the bank's performance: Evidence from Turkey. European Journal of Business and Management, 5(6), 130-140.

Freeman, R. E. (1994). The politics of stakeholder theory. Business Ethics Quarter, 4(4), 409-421. http://dx.doi.org/10.2307/3857340

Kutubi, S. S. (2001). Board of director's size, independence and performance: An analysis of private commercial banks in Bangladeshi. World Journal of Social Sciences, 1(4), 159-178. http://dx.doi.org/10.1007/s10690-007-9060-y

Latif, B., Shahid, M. N., Haq, M. Z., Waqas, H. M., \& Aeshad, A. (2013). Impact of corporate governance on firm performance: Evidence from sugar mills of Pakistan. European Journal of Business and Management, 5(1), 51-59. http://dx,doi.org//10.17541/oeybd.17415

Mmadu, R. A. (2013). Corporate governance and bank sector crisis in Nigeria: Rescue intervention or a Macabre dance with the economy? African Journal of Law and Criminology, 3(1), 83-109. Available at: www.sachajournals.com/mmadu

Mohammed, F. (2012). Impact of corporate governance on banks performance in Nigeria. Journal of Emerging Trends in Economics and Management Sciences, 3(3), 257-260. Available http://www.questia.com/library/journal/1P3-3112333621/impact-of-corporate-governance-on -banks-performance-in-nigeria

Pirsch, J., Gupter, S., \& Grau, S. L. (2007). A framework for understanding corporate social responsibility as a continuum: an exploratory study. Journal of Business Ethics, 70, 125-140. http://dx.doi.org/10.1007/s10551-006-9100-y

Sami, H., Wang, J., \& Zhou, H. (2009). Corporate governance and operating performance of Chinese listed firms. Journal of International Accounting, Auditing and Taxation, 152, 9-17

Suberu, O. J., \& Aremu, O. S. (2010). Corporate governance and merger activity in the Nigerian banking sector. Journal of Economics, 1(2), 91-97. Available at: www.krepublishers.com/

Uwuigbe, O. R. (2011). Corporate governance and financial performance of banks: A srudy of listed banks in Nigeria. Unpublished PhD Thesis, Covenant University, Ogun State. http://dx.doi.org/10.5539/ijef.v4n2p260

Uwuigbe, O. R., \& Fakile, A. S. (2012). The effects of board size on financial performance of banks: A study of listed banks in Nigeria. International Journal of Economics and Finance, $4(2), 260-267$.

Vo, D., \& Phan, T. (2013). Corporate governance and firm performance: Empirical evidence form Vietnam. http://www.murdoch.edu.au/School-of-Management-and-Governance-document/AustralianConference-of-Economists/corporate-governance-and-firm-performance.pdf 


\section{Macrothink}

Asian Journal of Finance \& Accounting ISSN 1946-052X 2015, Vol. 7, No. 1

Wessels, R., \& Wansbeek, T. (2014). What is the relation (if any) between a firm's corporate governance arrangements and its financial performance? CESifo Working paper 4599. Available at SSRN:http://ssrn.com/abstract=2393995

\section{Copyright Disclaimer}

Copyright for this article is retained by the author(s), with first publication rights granted to the journal.

This is an open-access article distributed under the terms and conditions of the Creative Commons Attribution license (http://creativecommons.org/licenses/by/3.0/). 